\title{
POLYMERS FROM BIOLOGICAL OILS
}

\author{
Z. S. Petrović \\ Kansas Polymer Research Center, Pittsburg State University, Pittsburg, Kansas, USA
}

\begin{abstract}
Vegetable oils, fish oil and oils from algae are excellent raw materials for new polymers. These oils differ in the structure and unsaturation, but each offer specific advantages. Vegetable oils are inexpensive and offer different degrees of unsaturation. Fish oils may have a very high degree of unsaturation. Algal oils are new raw materials with still unexplored possibilities. Most oils are triglycerides but cashew nut oil is an aromatic compound with a long hydrocarbon chain. Direct polymerization of oils has been used in coatings for a long time. Oils can be thermally polymerized by heating at a high temperature. The products are oligomers of high viscosity. We have developed a method for cationic polymerization of oils at mild conditions, useful as lubricants and modifiers for rubber, asphalt etc. However, for high strength materials, it is necessary to introduce functional groups such are hydroxyls, carboxyls, amine etc. Hydroxyls are the most useful ones, since they open the whole area of polyurethanes (foams, coatings, adhesives, elastomers and sealants). One can utilize the triglyceride structure or to use fatty acid derivatives, opening a wide field of combinations to suit different material requirements. This presentation will give a cross-section of different possibilities for creation of new materials from the biological oils.

Keywords: Polymers, vegetable oils, renewavle raw materials.
\end{abstract}

\section{INTRODUCTION}

Requirements for sustainability, solutions for ecological problems, and novel properties are the basis for the development of new bio-based materials. Biological (vegetable, animal, fish, and algae) oils are excellent renewable raw materials for new monomers and polymers. Most oils are triglycerides i.e., esters of glycerin and fatty acids, but some oils like cashew nutshell oil are not. Oils are considered non-reactive raw materials and in order to make them reactive one has to introduce functional groups. There are several sites in the triglyceride molecule suitable for the chemical attack: double bonds, ester bonds and allylic positions to double bonds as shown in Figure 1.

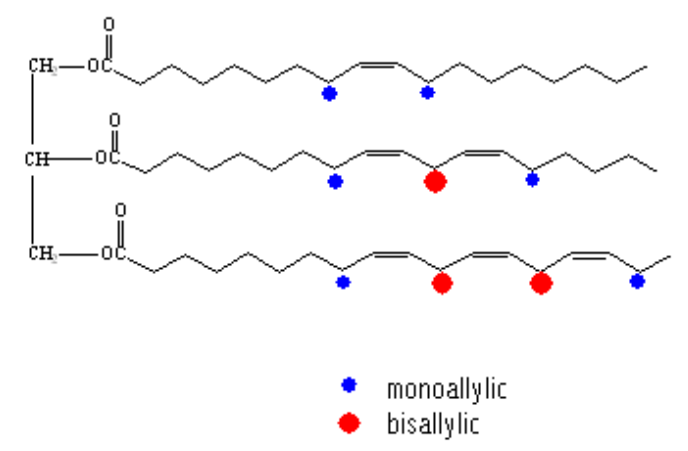

Figure 1. Illustration of a triglyceride molecule with ester bonds, double bonds and allylic position.
Various chemical reactions with double bonds can be performed but the most common are epoxidation and hydroformylation; while ester bond is used to make alkyd resins by transesterification and reaction with phthalic anhydride.

For industrial applications, soybean oil is the most abundant and least expensive in the United States and South America. Whereas in Europe its rapeseed oil; and in Asian countries its palm oil. As shown in table 1, palm oil has relatively low unsaturation. Rapeseed and soybean oils are semi-drying oils (IV=115-130) and linseed and fish oils are drying oils. The structure of algae oils vary with the type of algae in a wide range of compositions. Drying oils are used for coatings where polymerization is carried out by oxidation via allylic positions.

\section{POLYMERIZED OILS}

Polymerization of some oils (soybean, linseed) may be conducted thermally by heating above $300{ }^{\circ} \mathrm{C}$ giving so called "bodied oils". The process proceeds mainly through Diels-Alder addition and is followed with relatively high loss of material due to thermal degradation.

\footnotetext{
*Coresponding author: zpetrovi@pittstate.edu
} 
Table 1. Typical fatty acid compositions of palm, rapeseed, soybean, linseed, fish and algae oils ${ }^{a}$

\begin{tabular}{|c|c|c|c|c|c|c|c|c|c|c|c|c|c|c|}
\hline $\begin{array}{l}\text { Carbon atoms: } \\
\text { Double bonds }\end{array}$ & $14: 0$ & $16: 0$ & $16: 1$ & 18:0 & $18: 1$ & 18:2 & $18: 3$ & 20:0 & $20: 1$ & $20: 4$ & $20: 5$ & $22: 0$ & $22: 1 \quad 22: 6$ & $\begin{array}{l}\text { Iodine } \\
\text { value } \\
\text { range }\end{array}$ \\
\hline Palm oil & 1.0 & 44.4 & 0.2 & 4.1 & 39.3 & 10.0 & 0.4 & 0.3 & & & & 0.1 & & $50-55$ \\
\hline Rapeseed oil & 0.1 & 3.8 & 0.3 & 1.2 & 18.5 & 14.5 & 11.0 & 0.7 & 6.6 & & & 0.5 & 41.1 & $100-115$ \\
\hline Soybean oil & 0.1 & 10.6 & 0.1 & 4.0 & 23.3 & 53.7 & 7.6 & 0.3 & & & & 0.3 & & $123-139$ \\
\hline Linseed oil & & 6 & & 4 & 22 & 16 & 52 & 0.5 & & & & & & $>177$ \\
\hline Herring oil & $5-8$ & $10-19$ & $6-12$ & $1-2$ & $9-25$ & & & & $7-20$ & & $4-15$ & & $7-30 \quad 2-8$ & $115-160$ \\
\hline Microalgae ${ }^{c}$ & & 13.9 & 4.7 & 1.7 & 11.8 & 13.2 & 11.8 & & & 34 & & & & \\
\hline
\end{tabular}

${ }^{\text {a }}$ Some oil compositions may not add to $100 \%$ due to the presence of minor fatty acids.

${ }^{\mathrm{b}}$ 2003/4 figures. MMT - Million metric tons.

${ }^{\mathrm{c}}$ Parietochloris Incisa [1]

Cationic polymerization of oils in the presence of $\mathrm{BF}_{3}$ catalysts to obtain oligomeric oils has been described in literature and patents but the procedure required higher temperature and unstable catalyst $[2,3,4,5]$. We have developed a cationic polymerization of soybean and linseed oil at low temperature, without weight loss [6]. The degree of polymerization is dependent on the unsaturation of oils and time of reaction. The mechanism involves ene reaction displayed in the scheme 1 . The reaction in scheme 1 requires the presence of diene in the fatty acid (FA) structure, which form a cyclic structure with a double bond. Thus, oils with fatty acids containing only one double bond (oleic) do not polymerize but if linoleic is added then the polymerization occurs.

Schematic representation of the polymeric oils crosslinked by cyclic structures may appear as in scheme 2 .

\section{Formation of coniugated double bonds}

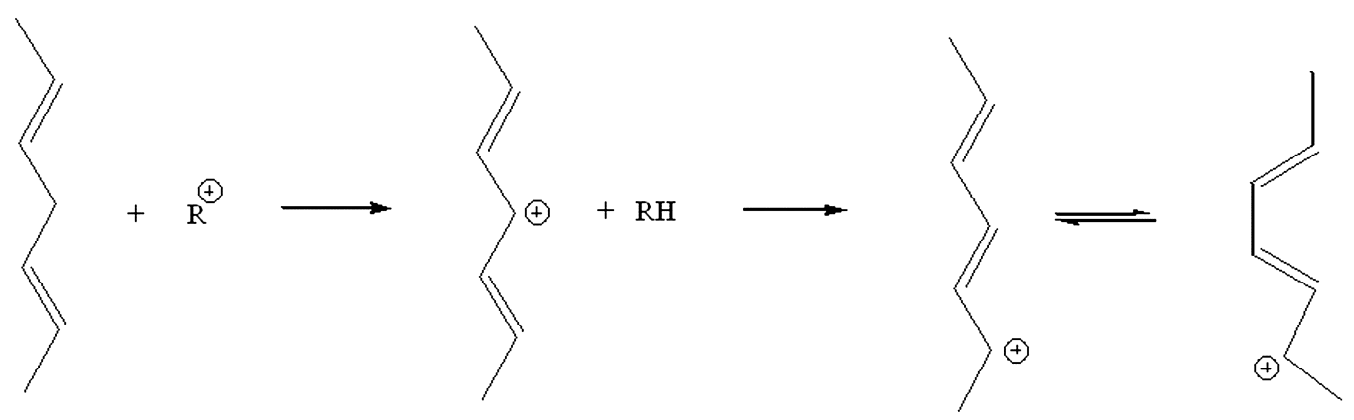

Diels-Alder reactions of conjugated double bonds
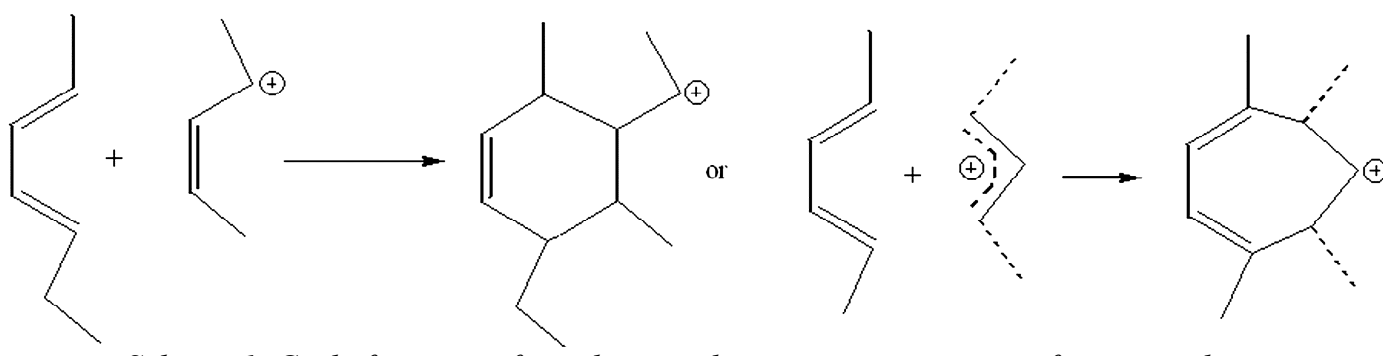

Scheme 1. Cycle formation from diene and monoene in presence of super acids.

Polymeric oils are viscose liquids or soft crosslinked gels, depending on molecular weight, which is controlled by the time of synthesis. Oils were copolymerized with styrene and divinyl benzene in the presence of Lewis acids $\left(\mathrm{BF}_{3}\right)$ to obtain rigid materi- als [7]. Polymerization through sulfur vulcanization was used to make Faktis (or factice), a product that was used as a processing in rubber technology. 


\section{EPOXY RESINS}

A large amount of epoxidized oils is used as plasticizer for PVC. However, epoxidized oils can be directly polymerized to give materials of different hardness [8,9].Again, super acids are good catalysts for cationic polymerization of internal epoxides. While terminal epoxides are traditionally reacted with amines, this reaction does not proceed with in- ternal epoxy groups. Polymerization of epoxides in the presence of acid catalysts occurs very fast, forming ethers. However, the structure of the product depends very much on the reaction conditions as demonstrated in the case of epoxydized oleic acid methyl ester (9-epoxymethyl stearate), where either cyclic or linear structures are formed as shown below.

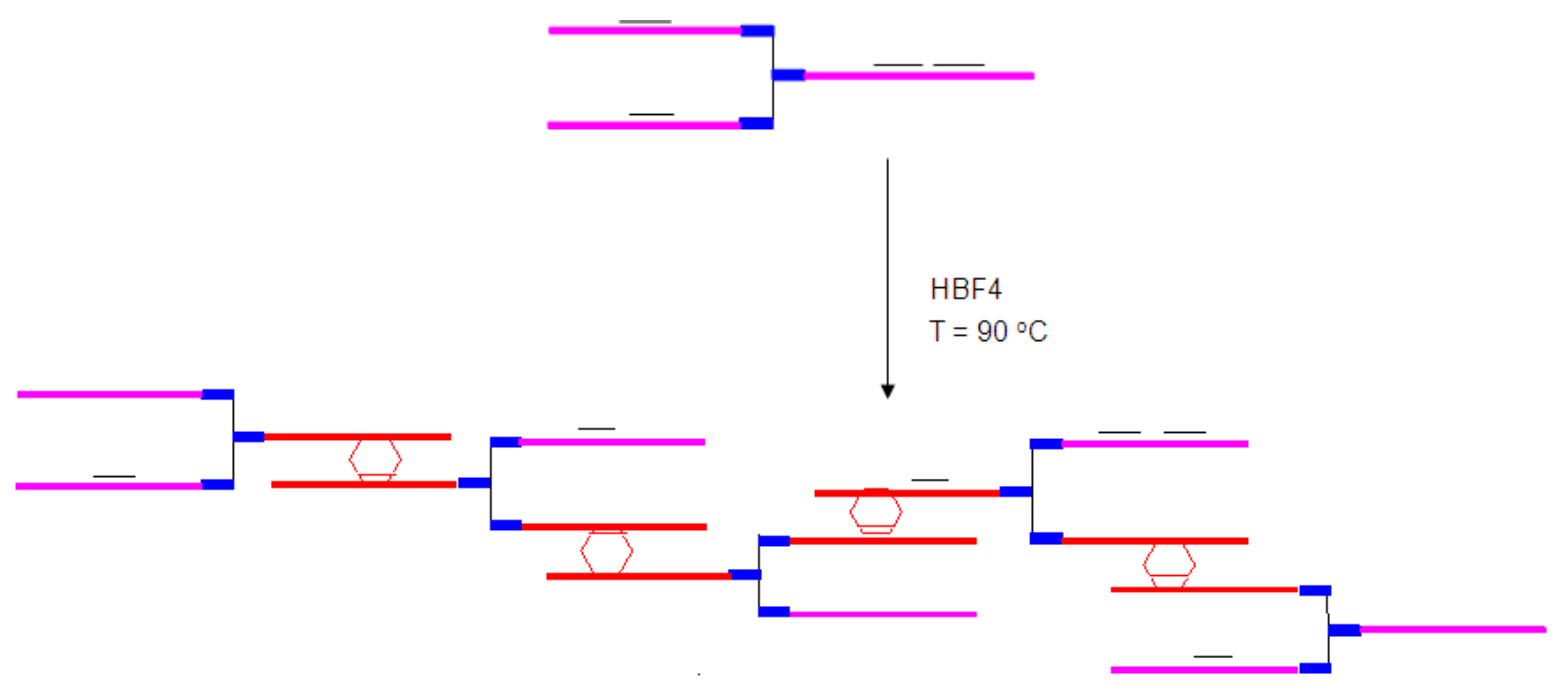

Scheme 2. Schematic representation of the polymerized triglyceride structure

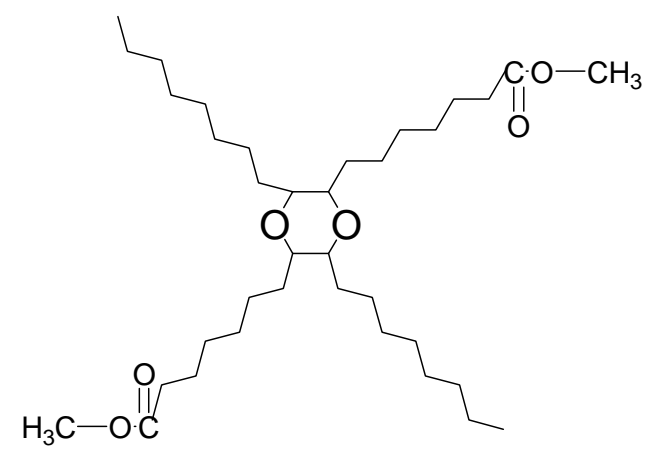

Cyclic dimer

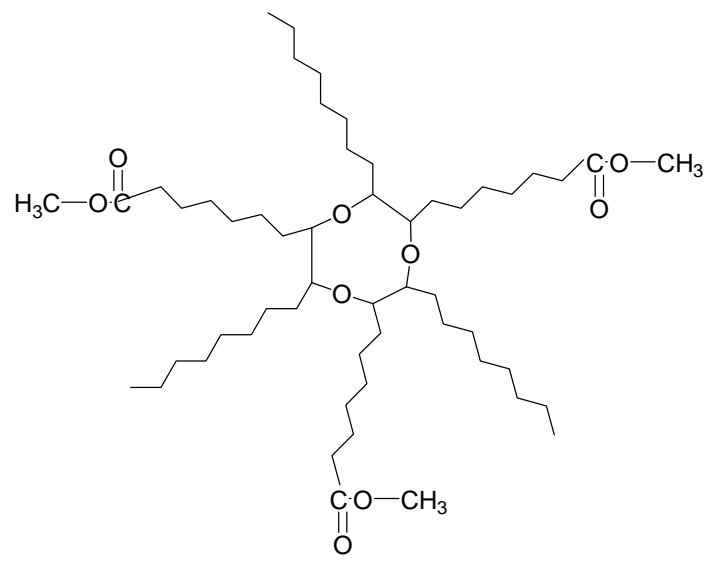

Cyclic trimer

The linear polymer formed in the presence of hydroxyl groups would have the probable structure:
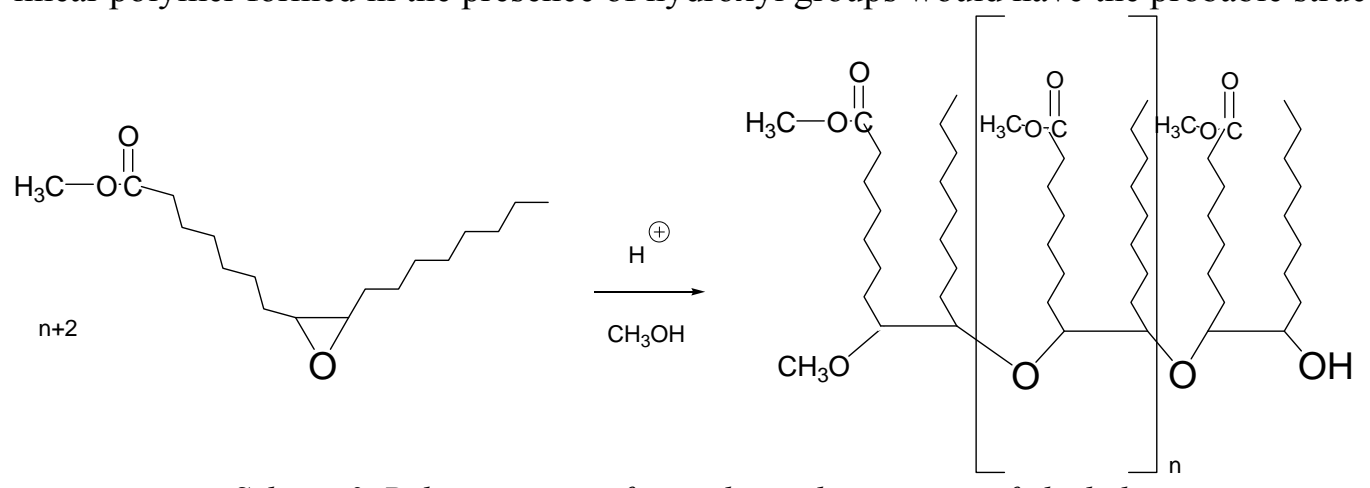

Scheme 3. Polymerization of epoxides in the presence of alcohol. 
In the presence of a high concentration of alcohol (methanol) ring opening of epoxy groups with hydroxyls result in the formation of ether and secondary hydroxyls but polymerization is limited to low

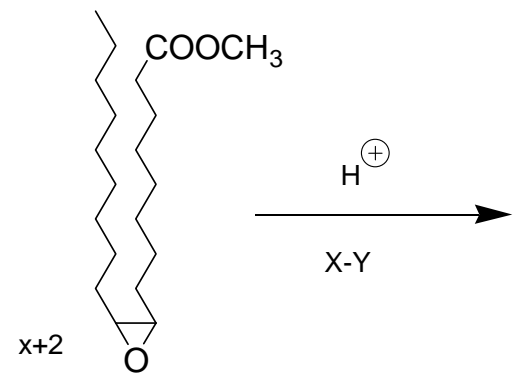

oligomers. Such reaction is used to make polyols for polyurethanes. In the absence of hydroxyl groups the linear structures are formed only from the catalyst $(\mathrm{X}-\mathrm{Y})$.

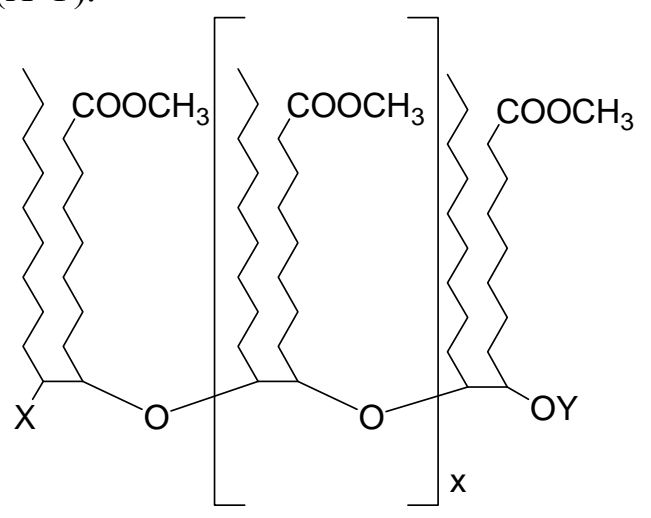

Scheme 4. Polymerization of epoxy fatty acid methyle esters in the abscence of hydroxyls.

Fatty acids with two or three epoxy groups (linoleic, linolenic) give higher content of cyclics (dioxane derivatives) even in the presence of excess of alcohols. Lewis acid catalysts have been used for curing of epoxides. One group of such catalysts are boron trifluoride $\left(\mathrm{BF}_{3}\right)$ based catalysts. $\mathrm{BF}_{3}$ is a gas and it is complexed with various alcohols, ethers or amines to give a liquid catalyst $[10,11]$. The blocked bo- ron trifluoride compounds are stable at room temperature but are deblocked at higher temperatures, initiating cationic polymerization. The mechanism is shown in the Scheme 5.

$$
\mathrm{BF}_{3} \cdot \mathrm{NHR}_{2} \stackrel{\Delta}{\rightleftharpoons} \mathrm{H}^{\oplus}+\mathrm{BF}_{3} \cdot \mathrm{NR}_{2}^{\ominus}
$$

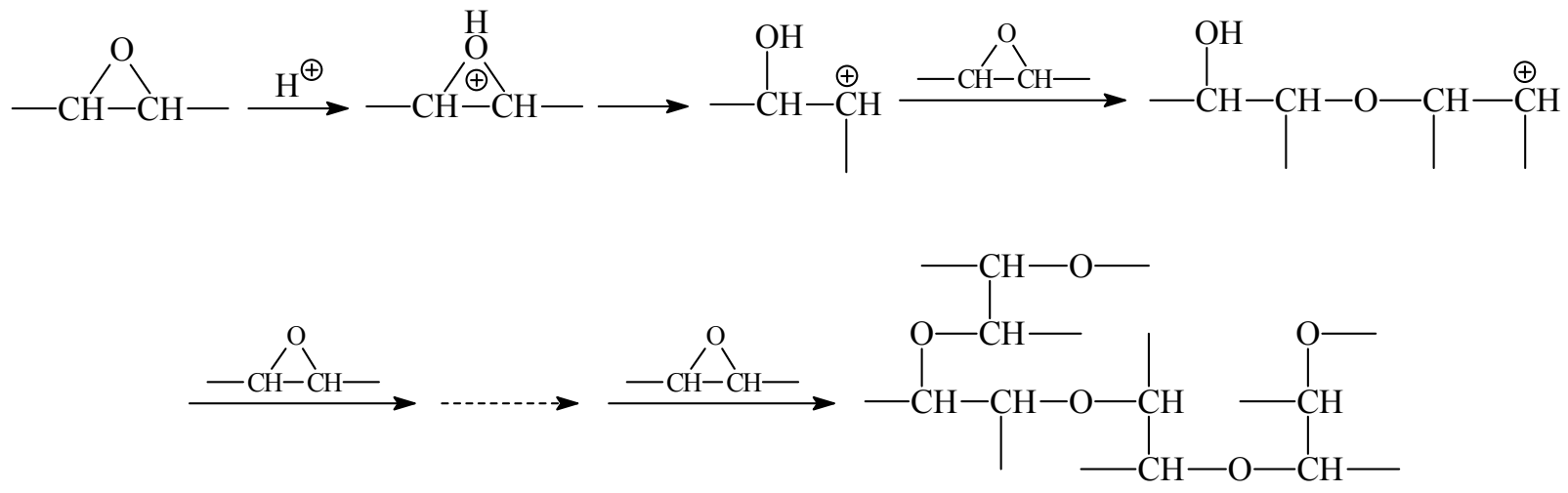

Polyepoxides

Scheme 5. Polymerization of epoxy resin to polyepoxides

Crosslinked vegetable oils with four epoxy groups per molecule such as from soybean oil give soft (elastomeric products) of relatively low strength and elongation. Epoxidized linseed oil gives somewhat harder materials with glass transition $\left(\mathrm{T}_{\mathrm{g}}\right)$ in the range $40-60{ }^{\circ} \mathrm{C}$, and of higher tensile strength, but not sufficient for a binder for strong fiber reinforced composites [8].

Epoxy resins obtained by curing epoxidized oils with aromatic and cycloaliphatic anhydrides produces materials of higher strengths and $\mathrm{T}_{\mathrm{g}}[12]$.
In this process, anhydride is opened by hydroxyls present in the system to form esters and free acid which may open epoxy groups resulting in new hydroxyl and polymerization through ether formation [13]. A hydroxyl group formed after ring opening of epoxy group with an acid can participate in ring opening polymerization of epoxides or react with acids to form an ester. Increasing anhydride content favors ester over ether formation, which is reflected in the higher strength of materials. 
<smiles>[R]OC(=O)c1ccc(C(=O)O)cc1C(=O)[O+]OC(=O)c1ccccc1</smiles>

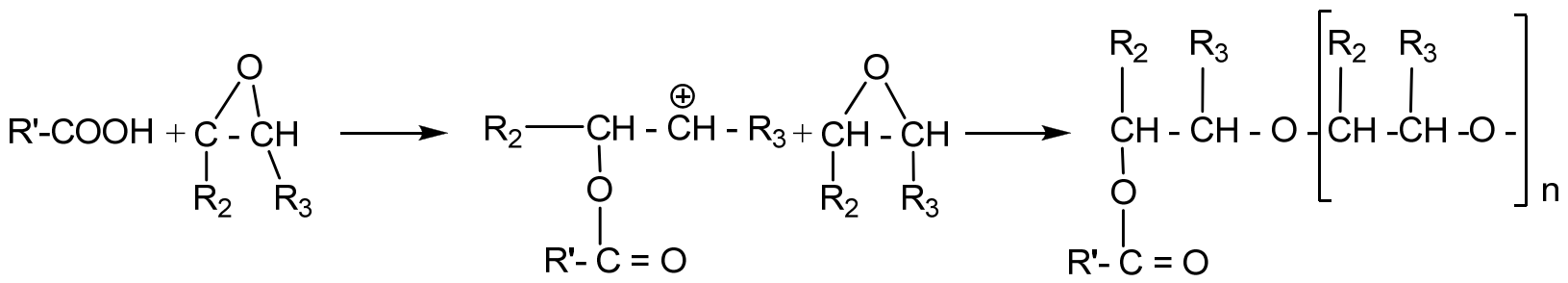

Scheme 6. Reaction of phthalic anhydride with epoxy groups. Anhydride reacts with a hydroxyl group present in the system and forms an acid that attacks the epoxy group in the second step.

The effect of epoxy/PA ratio was varied from $1 / 1$ to $1 / 0.125$ and with $2 \%$ catalyst (aluminum acetylacetonate). Tensile strength of the anhydride cured epoxidized soybean oil (ESBO) shows steady increase with increasing anhydride/epoxy ratio, Table 2 .

Table 2. Effect of epoxy/PA molar ratio on properties of epoxy resins

\begin{tabular}{|l|c|c|c|c|c|}
\hline Epoxy/PA molar ratio & $1 / 1$ & $1 / 1$ & $1 / 0.5$ & $1 / 0.25$ & $1 / 0.125$ \\
\hline Curing Temp., ${ }^{\circ} \mathrm{C}$ & 200 & 140 & 140 & 140 & 140 \\
\hline Curing time, $\mathrm{h}$ & 1 & 14 & 14 & 14 & 14 \\
\hline Gel time, min & 12 & 12 & 19 & 30 & 110 \\
\hline $\mathrm{T}_{\mathrm{g}},{ }^{\circ} \mathrm{C}(\mathrm{DSC})$ & 48 & 56 & 26 & -18 & -33 \\
\hline $\mathrm{T}_{\mathrm{g}},{ }^{\circ} \mathrm{C}(\mathrm{TMA})$ & 48 & 55 & 32 & -26 & -43 \\
\hline Hardness (Shore A) & 100 & 100 & 98 & 55 & 3 \\
\hline Tensile Strength, $\mathrm{MPa}$ & 18.5 & 28.5 & 4.0 & 0.07 & - \\
\hline Elongation, \% & 11 & 9 & 26 & 5 & - \\
\hline
\end{tabular}

Catalyst concentration was $2 \mathrm{wt} \%$

Aromatic anhydrides produce yellowing when exposed to sun light. Thus aliphatic and cycloaliphatic may be used for external applications. The best results with cycloaliphatic anhydrides were obtained with epoxidized linseed oil and methylhexahydrophthalic anhydride (MHHPA) (Figure 3) at 1:1 anhydride/epoxy ratio, displaying $\mathrm{T}_{\mathrm{g}}$ at $143{ }^{\circ} \mathrm{C}$, tensile strength of $40 \mathrm{MPa}$ and elongation at break of $4 \%$. MHHPA is a liquid at room temperature allowing easy handling.<smiles>CC1CCC2C(=O)OC(=O)C2C1</smiles><smiles>O=C(c1ccc2c(c1)C(=O)OC2=O)c1ccc2c(c1)C(=O)OC2=O</smiles><smiles>O=c1oc(=O)c2cc3c(=O)oc(=O)c3cc12</smiles>

Figure 3. Methylhexahydrophthalic anhydride, BTDA and PMDA.
High glass transitions can be obtained with dianhydrides, typically pyromellitic (PMDA) and benzophenonetetracarboxylic dianhydride (BTDA). Dianhydrides, however, have very high melting points and may be better used in solution. Thus, epoxy resins from epoxidized vegetable oils could be viable materials for engineering applications as binders for glass reinforced composites or mineral filled materials (artificial stone, marble). Epoxidized oils could be mixed with petrochemical epoxy resins to impart better impact resistance and decrease brittleness.

\section{POLYURETHANE RESINS}

Polyurethane resins and foams is the most significant group of products based on vegetable oils [14]. 
Polyurethanes are produced from polyols and isocyanates and only polyols are made from vegetable oil (there is one commercial oil-based diisocyanate but due to low reactivity it is used only in special coatings). Polyols are prepared from triglycerides or from fatty acids [15].

When bio-diesel is produced from vegetable oils, large quantities of glycerin are generated which could also be used for polyols. Vegetable oils are a valuable source for a range of chemicals and monomers for different polymers.

Preparation of polyols from epoxidized oil is the most common way of introducing hydroxyls in an ordered way. Ring opening can be carried out with a number of proton donors, such as organic and inorganic acids, alcohols, water or hydrogenation [16]. The reaction is shown in Scheme 6. The polyols are liquid when the substituent $\mathrm{Y}$ in the polyol (Scheme 6) are $\mathrm{RO}$ or $\mathrm{R}(\mathrm{O}) \mathrm{CO}-$ or $\mathrm{OH}$ and solid at room temperature when $\mathrm{Y}$ is $\mathrm{Cl}, \mathrm{Br}$ and $\mathrm{H}$. When completely crosslinked, polyurethanes are glassy solids with glass transitions varying with the number of $\mathrm{OH}$ groups and the type of the substituent $\mathrm{Y}$. Physical properties of some of these polyurethanes are described earlier [16].

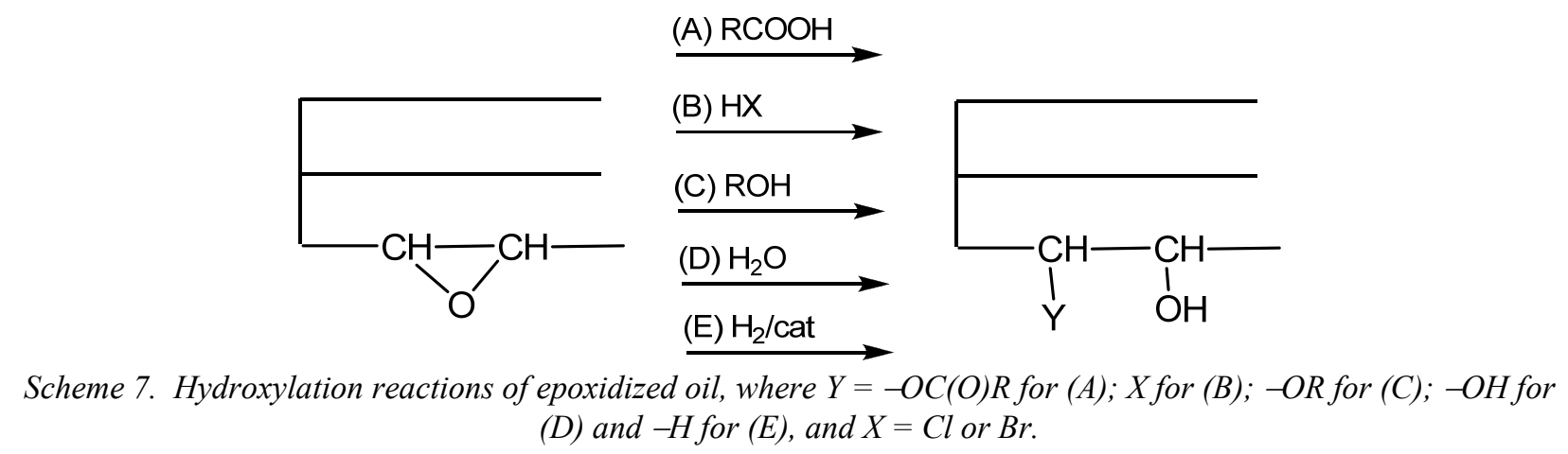

Another efficient way of introducing hydroxyls ikydroxyls [17]. The process is shown in scheme 7. Strucby hydroformylation. This is the reaction of double bondsure of two representative polyols by epoxidation/ring giving aldehydes, which are then hydrogenated tøpening and hydroformylation is given in Figure 4.

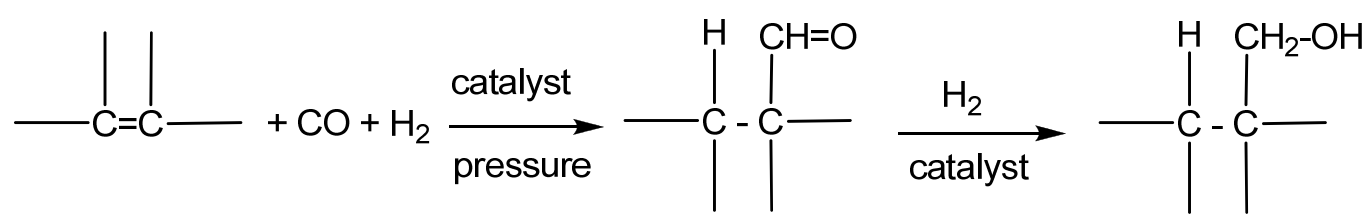

Scheme 8. Hydroformylation reaction

As scheme 7 shows, hydroformylation results in the introduction of an extra carbon per double bond. In soybean oil having 4.5 double bonds on average, the increase of molecular weight is $4.5 \times 32=$ 144 , or $16 \%$. Since glass transition, modulus and strength are inversely proportional to the molecular weight of network chains in crosslinked polymers, polyurethanes from hydroformylated polyols of the same functionality as epoxidation polyols are softer, lower Tg and less strong materials [18].

Since hydroformylation produces primary $\mathrm{OH}$ groups these polyols are more reactive than ones obtained via epoxidation. However, secondary hydroxyls can be converted to primary by ethoxylation or esterification with some lactones, e.g. caprolactone, but any additional step in synthesis increases the cost. The polyols discussed so far are of relatively low molar mass $(\sim 1000)$ and hydroxyl equivalent (200-300), suitable for rigid and semi-rigid applications (rigid foams, cast resins, coatings and adhesives). Another issue with these polyols is a wide functionality distribution ranging from 1 to $8 \mathrm{OH}$ groups per molecule [19].

Castor oil is a natural polyol with typically 2.7 $\mathrm{OH}$ groups per molecule. $\mathrm{OH}$ gives with diphenylmethane diisocyanate a hard elastomer with $\mathrm{Tg} \sim 7$ ${ }^{\circ} \mathrm{C}$. Polyols for flexible foams and elastomers require molar mass greater than 3000 and equivalent weight 1000 or higher. Such polyols can be prepared from hydroxy fatty acids, such as ricinoleic acid. 


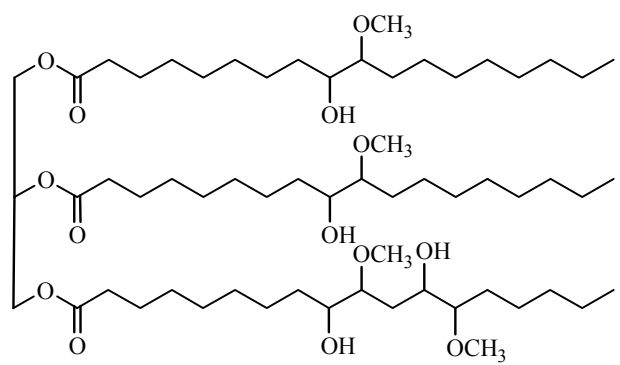

a)

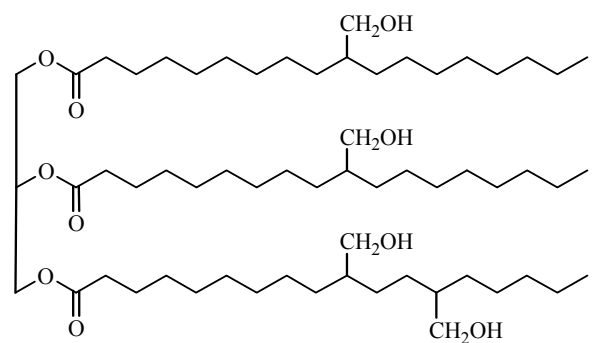

b)

Figure 4. Polyol structure obtained by epoxidation route (a) and hydroformylation route (b)

Preparation of difunctional or trifunctional polyols for elastomers and flexible foams from hydroxyl fatty acids is a simple process of transesterification. The illustration of the structure of diols obtained from polyricinoleic acid is shown in Figure 5. Instead of diol starters, one can use trimethylol pro- pane $(M=134.49)$ (triol) starter to generate triols but the chain structures would be the same as in Figure 5. One should note the existence of dangling chains in the structure of these polyols, which act as plasticizers, preventing crystallization and making softer polymers [20].

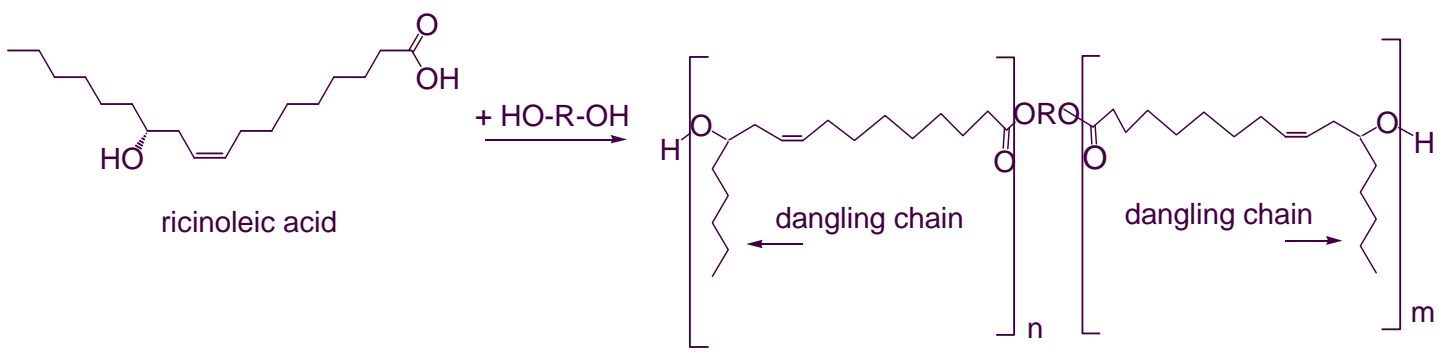

Figure 5. Polyester diol obtained from ricinoleic acid and a diol starter

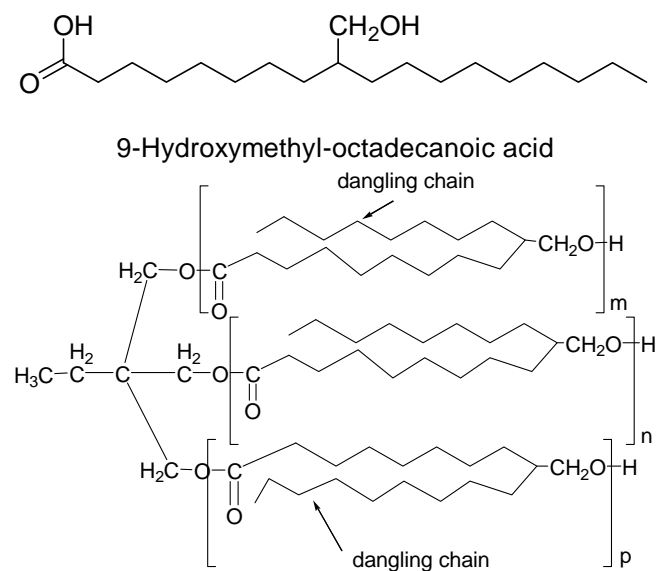

Triol from HFME and trimethylolpropane (TMP)

Figure 6. The monomer and triol from the same monomer and TMP

Excellent polymers were obtained from the hydroformylated oleic acid (9-hydroxymethyl-octadecanoic acid) or its methyl ester (HFME), by an analogous reaction. Molecular weight is controlled by the ratio of the starter (TMP) and HFME. By varying molar mass from 1000 to 4000 , viscosity increased from 2.6 to $11 \mathrm{~Pa}$.s. Polymers obtained by reacting these
Polyols with diphenylmethane diisocyanate (MDI) were crosslinked elastomers with glass transitions from -33 to $-58{ }^{\circ} \mathrm{C}$, tensile strengths from 7 to 0.7 $\mathrm{MPa}$, elongations from $47-110 \%$ and Shore A hardness from 85 to 33. Analogous polyurethanes from ricinoleic acid triol and MDI had lower glass transitions, lower hardness and higher elongations [21].

Especially interesting are thermoplastic polyurethanes (TPU) from these two hydroxyl fatty acid soft segments. TPU's can be processed by standard methods for thermoplastics such as injection molding, extrusion and thermoforming. TPU's are stronger materials than chemically crosslinked polyurethanes but their properties are more sensitive to temperature. Segmented polyurethane elastomers are block copolymers with alternating soft and hard blocks that, due to structural differences/incompatibility, separate into microphases or domains. Polymers with high soft segment concentration (SSC) are soft rubber with high elongations and are distinguished by dispersed hard domains in the matrix of soft segments, while those with lower SSC $\sim 50 \%$ are hard rubbers, characterized by co-continuous both hard and soft phases, Figure 7. 

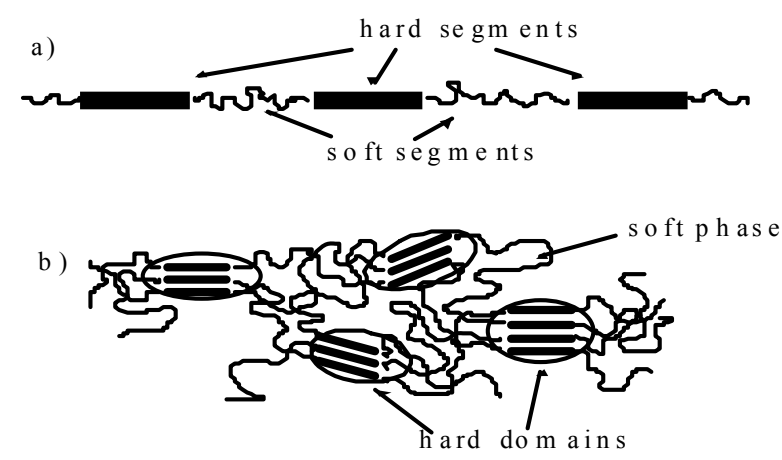

C)

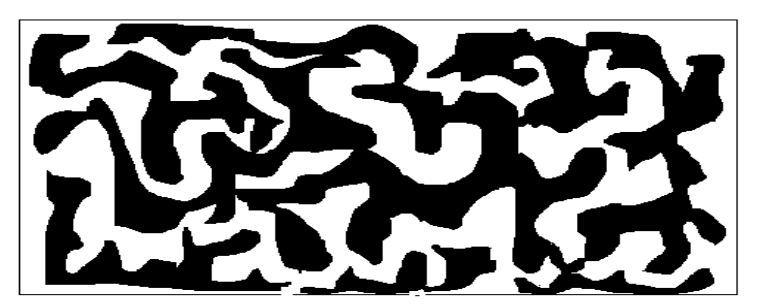

Figure 7. Structure of the alternating soft and hard segments (a), dispersed hard domains in the soft phase (b) and co-continuous morphology (c).

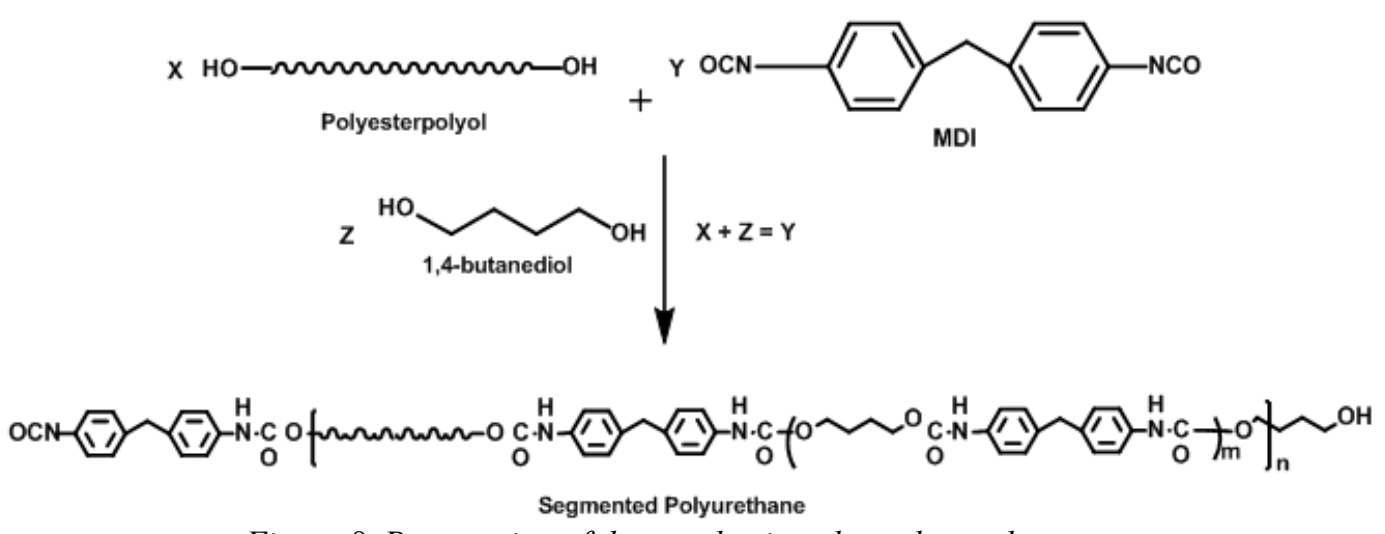

Figure 8. Preparation of thermoplastic polyurethane elastomers

Preparation of TPU's from ricinoleic ethyl esters consists in synthesis of diols of molecular weights between 2000 and 4000, reaction with the excess of diisocyanate to obtain a prepolymer with terminal NCO groups and chin extension with a diol. The process is illustrated in Figure 8.

When soft segments in our TPU's was from ricinoleic acid and hard segments from MDI and butane diols, elastomers with good physical properties were obtained [22]. Stress-strain curves for polymers with SSC from 40-70\% SSC are given in Figure 9.

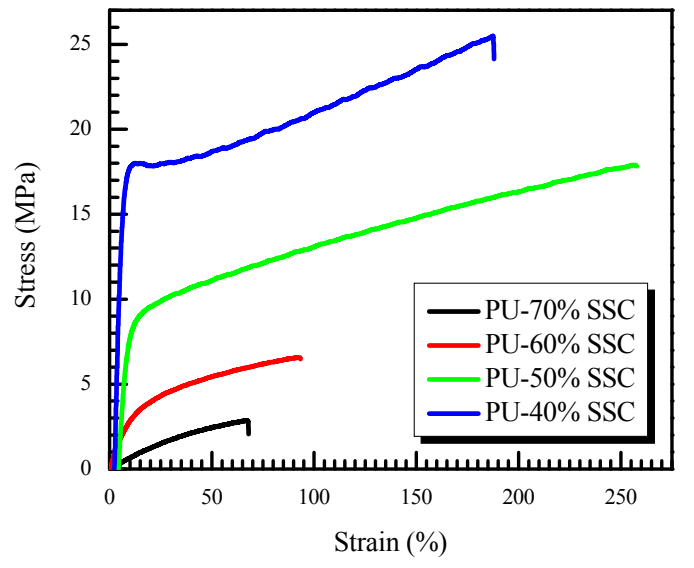

Figure 9. Stress strain curves for TPUS based on polyricinoleic soft segments and MDI/BD hard segments, with varying $S S C$. 


\section{FOAMS}

A major application of oil-based polyols is in rigid and flexible foams. While rigid foams can be made from $100 \%$ oil-based polyols, additional research is required to make polyols which will satisfy the requirements in flexible foams. Foams are special materials, composites gas/solid and the science of controlling structure and properties of foams is fascinating, but it is beyond the scope of this presentation. At this stage bio-based polyols are used in conjunction with petrochemical polyols up to a maximum of $40 \%$. There are several issues with polyols for flexible applications, one being heterogeneity of functionalities compared to petrochemical polyols. The preparation of polyurethanes from hyperbranched polyols made by transesterification of hydroxy fatty acids gives high molecular weight, acceptable viscosity and higher functionality components for flexible foams and adhesives. It should be emphasized that oil based polyurethanes are new materials and a new approach is needed to create novel materials. The economics of oil-based polyols will depend largely on the oil/petrochemical price.

\section{USEFUL MONOMERS AND POLYMERS FROM FATTY ACIDS}

Some interesting monomers for polyesters or polyamids are obtained from fatty acids. Ozonolysis of oil produces aldehyde, carboxyl, amino or hydroxyl groups at the position of double bonds if oxidation or reduction is applied, as shown in Figure 10. The product of ozonolysis is a trygliceride with functional groups at the 9th carbon and a range of mono or difunctional species. The polyesters similar to polycaprolactones was prepared from hydroxy nonanoic acid methyl ester [23,24]. This polyester has a very simple structure as shown in Scheme 8, and due to a highly regular structure crystallizes fast. It has a melting point at $70-74{ }^{\circ} \mathrm{C}$ and glass transition below room temperature. It is completely bio-based and may be biodegradable.<smiles>[X]C(=O)CCOCC</smiles>

Scheme 9. Polyhydroxynonanoate
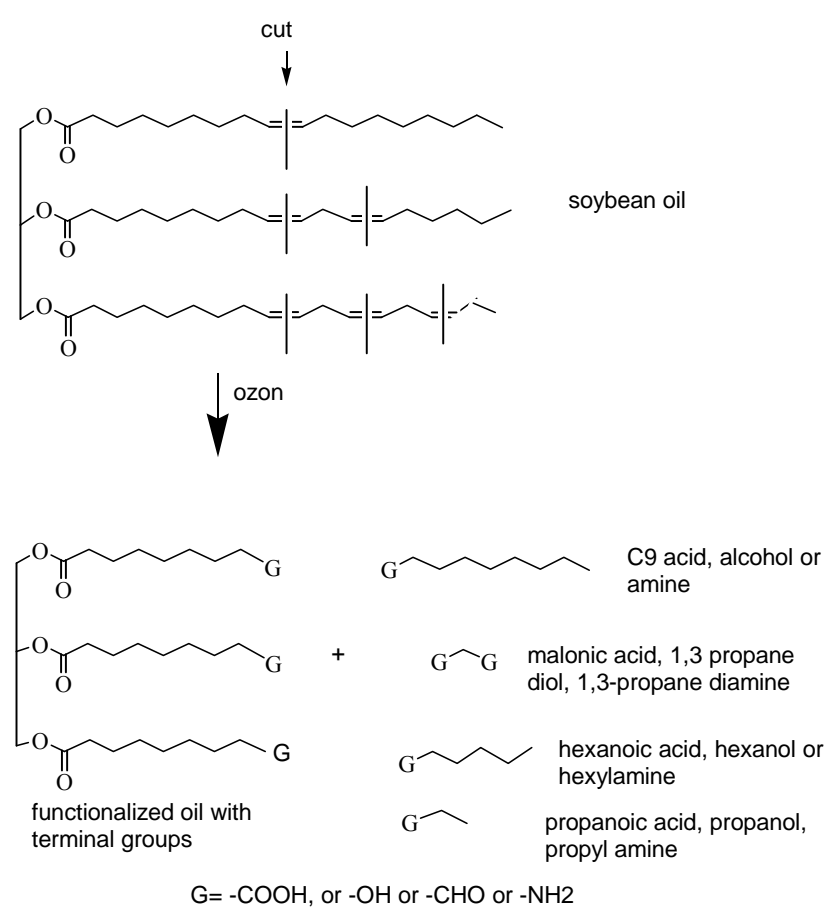

Figure 10. Ozonolysis products from soybean oil

When terminal groups are hydroxyls then the triglyceride is a triol that can be converted by methanolysis to methyl esters of 9-hydroxy nonanoic acid and glycerin. If the terminal group is carboxyl then the product of methanolysis would be dimethyl ester of azelaic acid. Both monomers can be used to produce polyesters or polyester diols for polyurethanes in combination with a diol. 9-aminononanoic acid can self-polymerize to give polyamide 9 . It should be noted that Nylon 11 was for a long time commercially available (Rilsan-ATOCHEM). It is obtained from 11 aminoundecanoic acid, a product of thermal breakdown of ricinoleic acid (C18) to $\mathrm{C} 11$ and $\mathrm{C} 7$ as shown in Figure 11. Using basic conditions in the second step, the reaction will produce from $\mathrm{C} 18$ two components: $\mathrm{C} 10$ and $\mathrm{C} 8$ [25].

Reacting epoxidized oils or fatty acids with carbon dioxide one can generate carbonate groups, which by reacting with amines give urethanes [26].

The non-isocyanate route to oil-based polyurethanes is displayed in Figure 12. The list of products shown in this paper is only a section of all oleochemicals and the product list is limited by scientist's imagination. 

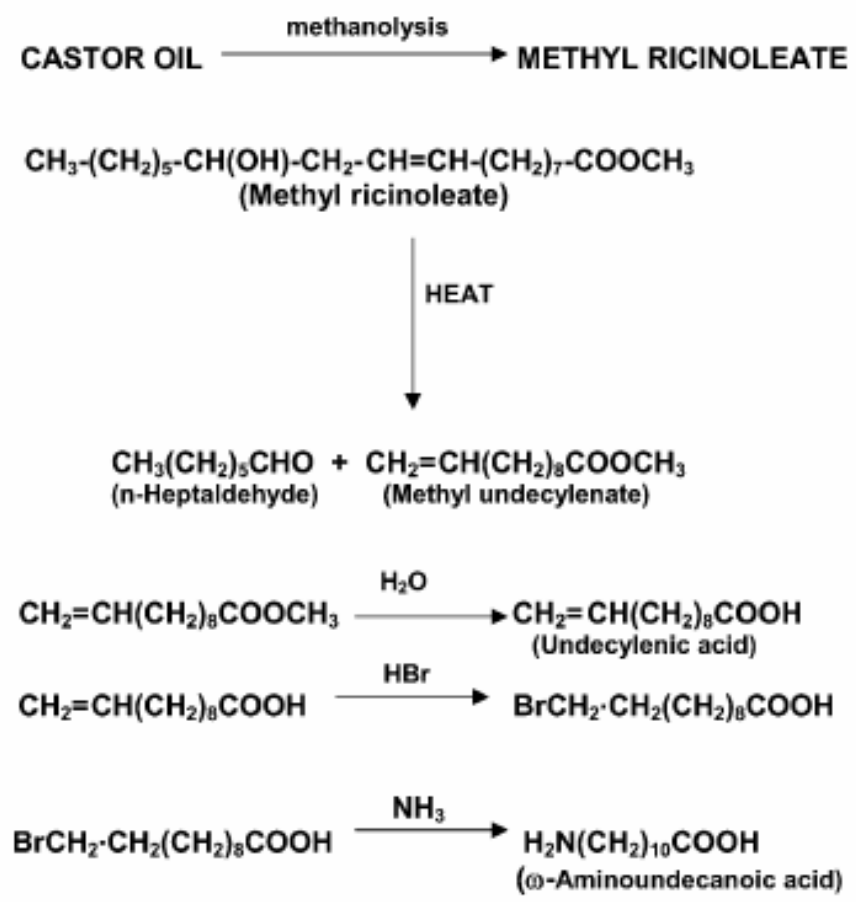

Figure 11. Preparation of $\omega$-aminoundecanoic acid from castor oil

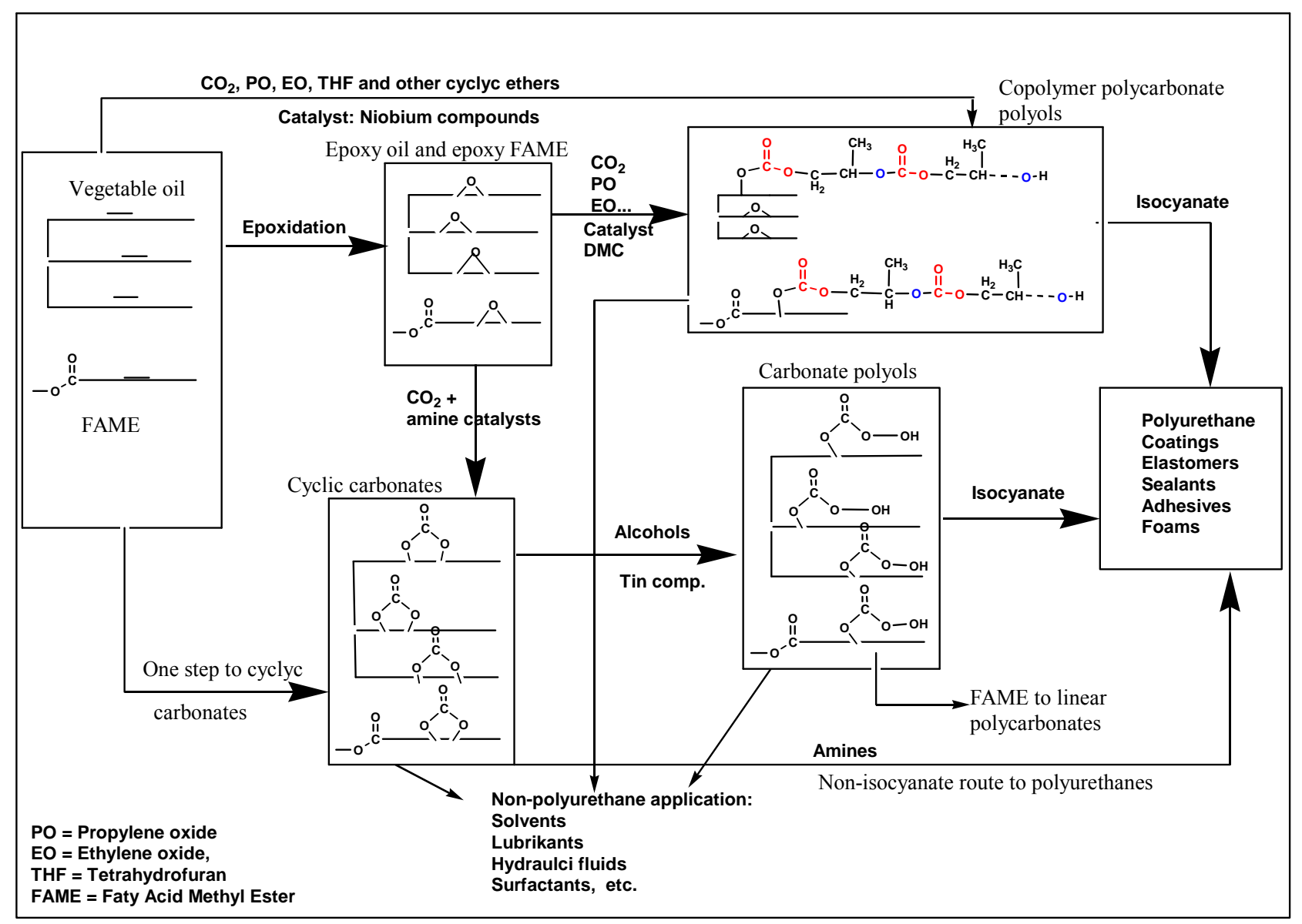

Figure 12. Synthetic routes for synthesis of different bio-based polycarbonates 


\section{CONCLUSION}

Biological oils are an excellent source of renewable materials for very different applications. This promising field is growing because of ecological and economical concerns.

\section{REFERENCES}

[1] Z. Kohen, C. Rathledge, Single Cell Oils, p.61; AOCS Press: Champaign, Illinois, 2005.

[2] C. B. Croston, I. L. Tubb, J. C. Cowan, H. M. Teeter, JOACS 1952, 29, 331-333.

[3] E. Eichwald, US. Pat. 2,160,572, 1939.

[4] R. Uloth, M. Mueller-Cunradi, U.S.Pat. 2,365,919, 1944.

[5] S. M. Ghodssi, A. J. Petit, H. Valot, Bulletin de la Societe Chimique de France 1970, 14611466.

[6] M. Ionescu, Z. S. Petrovic, U.S. Pat. 7, 501, 479, 2009.

[7] R. C. Larock, H. Marck, U.S. Pat. 6, 211, $315,2001$.

[8] J. V. Crivelo, R. Narayan, S. S. Sternsein, J. Appl. Polym. Sci. 1997, 64, 2073-2870.

[9] S. Warwel, E. Fehling, M. Kunz, Eur. J. Lipid Sci. 2001, 103, 133-140.

[10] Z. Liu, S. Z. Erhan, Journal of the American Oil Chemists' Society 2010, 87, 437-444.

[11] Z. Liu, K. M. Doll, R. A. Holser, Green Chem. 2009, 11, 1774 - 1780.

[12] J. Rosch, R. Mulhaupt, Polymer Buletin 1993, 31, 697-685

[13] J.-P. Pascault, R. J. J. Williams, General Concepts about Epoxy Polymers, in Epoxy Polymers; WILEY-VCH Verlag GmbH \& Co. KGaA: Weinheim, 2010.
[14] Z. S. Petrovic, Polymer Reviews 2008, $48,109-155$.

[15] Z. S. Petrović, M. Lukić, W. Zhang, W. Shirley, Fatty Acid - Based Polyols And Polyurethanes; Academy of Science and Arts of Serbian Republic, Scientific Sessions vol VII , Section of natural, Mathematical and Technical Sciences vol.4, Theoretical and Experimental Investigation of Nanomaterials, Banja Luka, 2005.

[16] A. Guo, Y.-J. Cho, Z. S. Petrovic, J. Polym.Sci. Part A: Polym. Chem. 2000, 38, 39003910.

[17] P. Kandanarachchi, A. Guo, Z. Petrovic, Journal of Molecular Catalysis A 2002, 184, 65-71.

[18] A. Guo, D. Demydov, W. Zhang, Z. S. Petrovic, J. Polymers and Environment 2002, 10, 49-52.

[19] Z. S. Petrovic, L. Yang, A. Zlatanic, W. Zhang, I. Javni, J.Appl.Polym.Sci. 2007.

[20] Z. S. Petrovic, I. Cvetkovic, D. Hong, X. Wan, W. Zhang, T. Abraham, Malsam, J. Journal of Applied Polymer Science 2008, 108, 1184-1190.

[21] Z. S. Petrovic, I. Cvetkovic, D. Hong, X. Wan, W. Zhang, T. W. Abraham, Malsam, J. European Journal of Lipid Science and Technology 2010, 112, $97-102$.

[22] Y. Xu, Z. S. Petrović, S. Das, G.L. Wilkes. Polymer 2008, 49 4248-4258.

[23] I. Cvetković, J. Milić, M. Ionescu, Z. S. Petrović, Hem. ind. 2008, 62 319-328

[24] Z. S. Petrovic, J. Mili, Y. Xu, I. Cvetkovic, Macromolecules 2010, 43 4120-4125.

[25] D. S. Ogunniyi, Bioresource Technology 2006, 97 1086-1091.

[26] I. Javni, D-P. Hong, Z. S. Petrovic, Journal of Applied Polymer Science 2008, 108, 3867 -3875 .

\title{
ПОЛИМЕРИ ОД БИОЛОШКИХ УљА
}

\begin{abstract}
Сажетак: Биљна уља, рибље уље и уље од алги одличне су обновљиве сировине за нове полимере. Она се разликују међу собом по структури и степену незасићености, али свако од њих нуди посебне предности. Биљна уља су јефтина и имају различите степене незасићености. Рибља уља могу имати висок степен незасићености. Уља од алги су нове сировине са још неистраженим могућностима. Већина уља су триглицериди али уље из каше љуске ораха је аромат са дугим угљоводоничним ланцима. Директна полимеризација уља је већ дуго коришћена за превлаке. Уља се могу полимеризовати термичким грејањем на високој температури. Производи су олигомери велике вискозности. Ми смо развили метод катјонске полимеризације уља у благим условима, која се могу користити као мазива, модификатори за гуму, асфалт итд. Међутим, да би се добили материјали велике чврстоће потребно је увести функционалне групе као што су хидроксилне, карбоксилне, аминске, и сл. Хидроксилне групе су најповољније јер отварају читаво подручје полиуретана (за пе-
\end{abstract}


не, превлаке, адхезиве, еластомере и заптивне масе). Уља се могу користити у облику триглицерида или разбијена у деривате масних киселина отварајући тиме широко подручје комбинација да би се задовољили различити захтеви код материјала.

Ова презентација даје пресек различитих могућности креирања нових материјала од биолошких уља.

Кључне речи: полимери, биљна уља, обновљиве сировине.

$\cos 80$ 